DOI: https://doi.org/10.32838/2523-4803/71-4-2

удК 338.2

\author{
Молдован 0.0 . \\ кандидат економічних наук, докторант відділу економічної стратегії \\ центру економічних і соціальних досліджень, \\ Національний інститут стратегічних досліджень; \\ директор Центру політичних та економічних ініціатив \\ «Європейська стратегія» \\ ORCID: https://orcid.org/0000-0002-3776-6291
}

\title{
Moldowan Aleksy
}

Economic Strategy Department

Center for Economic and Social Research,

National Institute for Strategic Studies;

Centre for Political and Economic Initiatives «European Strategy»

\section{ЕКОНОМІЧНА БЕЗПЕКА ДЕРЖАВИ ЯК БАЗОВЕ ПОНЯТТЯ ЕКОСЕСТЕЙТУ: У ПОШУКАХ УНІВЕРСАЛЬНОЇ ДЕФІНІЦЇ̈}

У статті обтрунтовується теза про те, щзо теорія економічної безпеки держави як наукова дисциилліна сьогодні перебуває на початковій стадії нового етапу розвитку. Водночас підкреслено, щуо ия наукова дисципліна повною мірою не готова до низки викликів. Одна з ключових проблем, яка стримуватиме потениіал розвитку екосестейту, полягає у тому, щзо в рамках иієї наукової дисципліни існує значна кількість наукових шкіл, більшість із яких використовує власний категоріально-понятійний апарат. При иьому суттєві відмінності починаються вже на етапі окреслення базової дефініції зазначеної наукової дисиипліни - економічної безпеки держави. Це є суттєвою перешкодою для конструктивної наукової дискусії між різними фахівиями в рамках екосестейту. Із критичного погляду проаналізовано підходи різних наукових шкіл та окремих науковців до визначення поняття «економічна безпека держави». Завдяки иьому ідентифіковано ӥхні переваги та недоліки. Із метою запровадження універсальної дефініиії запропоновано власне визначення економічної безпеки держави як базового поняття екосестейту, також обтрунтовано дочільність застосування запропонованого підходу.

Ключові слова: теорія економічної безпеки держави, екосестейт, економічна безпека держави.

Постановка проблеми. В умовах наростання глобальної економічної нестабільності, посилення боротьби за ресурси й ринки між ключовими акторами світової політичної арени та актуалізації нових загроз (кліматичні зміни, неконтрольована міграція, пандемія коронавірусу тощо) поступово відновлюється статус держави як гаранта забезпечення економічної безпеки суспільства та громадян. У зв'язку із цим науковий i прикладний інтерес до проблематики економічної безпеки держави в останні роки стрімко зростає, а сама 
дисципліна постала перед потребою нового якісного розвитку.

На жаль, методологічна інституціоналізація теорії економічної безпеки (екосестейту) на сучасному етапі не встигає за зростанням попиту на наукові дослідження із цієї тематики. Однією з ключових проблем залишається надмірна фрагментація наукової спільноти, яка працює у цьому напрямі. У рамках екосестейту нині функціонують десятки автономних наукових шкіл, кожна з яких оперує власною термінологією, розробленою спеціально для проведення власних прикладних досліджень. Такі особливості ускладнюють формування єдиної експертної спільноти, яка б попри свої відмінності мала б спільну платформу для співпраці в рамках однієї наукової дисципліни.

Аналіз останніх досліджень і публікацій. Теорія економічної безпеки держави $є$ досить динамічною науковою дисципліною. Через особливу практичну цінність досліджень у цій сфері наукова спільнота повсякчас була переважно сконцентрована на вирішенні конкретних прикладних завдань, що є актуальними для певної історичної епохи, у якій працюють дослідники. Такі знані світові та вітчизняні науковці, як Б. Бузан, В. Кейбл, Г. Маховскі, Х. Мауль, С. Мардок, П. Робінсон, Б. Тейлор, С. Пирожков, В. Горбулін, Я. Жаліло, О. Власюк та ін., зробили значний внесок в інституціоналізацію й розвиток теорії економічної безпеки держави. Вони досліджували досить важливі аспекти тематики, що належать до сфери інтересів теорії економічної безпеки держави.

Значно менше уваги в рамках теорії економічної безпеки держави фахівці приділяють теоретико-методологічним питанням. Незважаючи на те що змістовні дослідження в рамках цієї дисципліни здійснюються вже протягом століття, теорії економічної безпеки держави відчутно бракує фундаментальних наукових праць, які створювали би спільну методологічну платформу для значної кількості наукових шкіл, що працюють у цьому напрямі в різних країнах. Однією 3 найбільш важливих проблем, які, з нашої точки зору, істотно сповільнюють темп становлення теорії економічної безпеки як зрілої наукової дисципліни, є відсутність наукового консенсусу щодо розуміння феномену економічної безпеки держави.

Формулювання цілей статті. Метою статті $\epsilon$ дослідження різних підходів до тлумачення поняття «економічна безпека держави» 3 метою опрацювання загальноприйнятої дефініції, яка могла б стати базовою в рамках екосестейту.

Виклад основного матеріалу. У науковій думці процес становлення та визначення чітких меж категоріально-понятійного апарату економічної безпеки ще не досягнув усталеності, унаслідок чого на поточний момент існує декілька підходів до визначення поняття «економічна безпека держави». На підставі аналізу різних дефініцій можемо виокремити шість основних поширених підходів до визначення цього наукового поняття.
Відповідно до першого (кондиціонального) підходу, економічна безпека трактується як сукупність певних умов, які забезпечують реалізачію визначених державою завдань. Зокрема, Л. Абалкін розглядає економічну безпеку як «сукупність умов і факторів, що забезпечують незалежність національної економіки, її стабільність і здатність до постійного оновлення і самовдосконалення» $[1$, с. 5]. А. Іларіонов уважає, що економічна безпека - це «поєднання економічних, політичних i правових умов, що забезпечує в довгостроковій перспективі виробництво максимальної кількості економічних ресурсів на душу населення найбільш ефективним шляхом» [2, с. 35].

Згідно з підходом С. Пирожкова, економічна безпека - «це сукупність умов, за яких країни зберігають свої економічні інтереси; задовольняють у довгостроковому періоді потреби суспільства і держави; генерують інноваційні зрушення в економіці для забезпечення стабільного економічного розвитку; протистоять зовнішнім економічним загрозам та повністю використовують національні конкурентні переваги у міжнародному поділі праці» [3, с. 14].

А. Сухоруков, своєю чергою, стверджує, що під економічною безпекою необхідно розуміти «сукупність умов, за яких зберігається здатність країни підтримувати конкурентоспроможність економіки, ефективно захищати національні економічні інтереси і протистояти зовнішнім економічним загрозам, повністю використовувати конкурентні переваги в міжнародному поділі праці» [4, с. 53].

О. Ляшенко зазначає, що економічна безпека являє собою сукупність внутрішніх і зовнішніх умов, які сприяють ефективному динамічному зростанню національної економіки, іiї здатності задовольняти потреби суспільства, держави, індивіда, забезпечувати конкурентоспроможність на зовнішніх і внутрішніх ринках, що гарантує захист від різного роду загроз і втрат [5, c. 43-44].

У рамках другого (якісного) підходу економічну безпеку фахівиі тлумачать як найважливішу якісну характеристику економічної системи, щзо визначає ї̈ здатність підтримувати нормальні умови функиіонування та діяльності ключових учасників: держави, бізнесу та громадян. Зокрема, на думку Я. Жаліла, «економічна безпека може бути визначена як складна багатофакторна категорія, що характеризує здатність національної економіки до розширеного самовідтворення з метою задоволення на визначеному рівні потреб власного населення і держави, протистояння дестабілізуючій дії чинників, що створюють загрозу нормальному розвитку країни, забезпечення конкурентоспроможності національної економіки у світовій системі господарювання» [6, с. 102].

Досить лаконічно, але змістовно, у рамках означеного підходу економічну безпеку держави трактує Й. Янг. На думку автора, це «здатність держави забезпечити постійне підвищення рівня життя всього населення за рахунок національного економічного 
розвитку за збереження економічної незалежності» [7, c. 67].

Своєю чергою, М. Срмошенко зазначає, що економічна безпека характеризується збалансованістю і стійкістю до негативного впливу внутрішніх і зовнішніх загроз, здатністю забезпечувати на основі реалізації національних економічних інтересів сталий та ефективний розвиток вітчизняної економіки й соціальної сфери [8, с. 29].

У рамках якісного підходу Б. Губський окреслив поняття економічної безпеки як «можливість і готовність економіки забезпечити достатні умови життя i розвитку особи, соціально-економічну і військовополітичну стабільність суспільства і держави, протидіяти впливу внутрішніх і зовнішніх загроз» [9, с. 17].

В основі третього (протекиіоністського) підходу до трактування економічної безпеки перебуває категорія захищеності, у т. ч. держави, бізнесу та громадян, від внутрішніх та зовнішніх загроз. Так, на думку В. Савіна, економічна безпека - це «система захисту життєвих інтересів країни. Об'єктами такого захисту виступають: народне господарство країни у цілому, окремі регіони, сфери і галузі господарства, юридичні та фізичні особи як суб'єкти господарської діяльності» $[10$, c. 23$]$.

Т. Сак зазначає, що економічну безпеку необхідно розуміти у комплексі: як стан захищеності національних інтересів, а також як наявність і можливість застосування інструментів впливу на економічні процеси для гарантування добробуту в довгостроковому періоді [11, c. 337].

На думку В. Сенчагова, економічна безпека - такий «стан економіки та інститутів влади, за якого забезпечується гарантований захист національних інтересів, соціально спрямований розвиток країни загалом, достатній оборонний потенціал навіть за найбільш несприятливих умов розвитку внутрішніх і зовнішніх процесів» [12, с. 99].

У рамках четвертого (статичного) підходу до трактування економічної безпеки держави џе поняття розкривається через визначення певного стану економіки, який дає змогу державі реалізовувати ї̈ функиії та протидіяти зовнішнім і внутрішнім загрозам. Зокрема, один з основоположників теорії економічної безпеки в України Г. Пастернак-Таранушенко запропонував визначення економічної безпеки як «стану держави, за якого вона забезпечена можливістю створення та розвитку умов для плідного життя іï населення, перспективного розвитку іï економіки в майбутньому та в зростанні добробуту ії мешканців» [13, с. 29].

Науковці В. Шлемко та І. Бінько вважають, що економічна безпека - це «такий стан національної економіки, який дає змогу зберігати стійкість до внутрішніх i зовнішніх загроз і здатний задовольнити потреби особи, сім'ї, суспільства, держави» [14, с. 8].

Із точки зору В. Андрійчука, економічна безпека це «стан економічної системи, який дає їй змогу розвиватися динамічно, ефективно і вирішувати соціальні завдання та за якого держава має можливість виробляти і втілювати в життя незалежну економічну політику» [15, с. 14].

Зазначимо, що визначення економічної безпеки державою через характеристику іiї стану домінує в наукових школах деяких східноєвропейських країн (Польща, Литва, Словаччина та ін.). Зокрема, один з основоположників теорії економічної безпеки в науковій думці Польщі 3. Стаховяк визначає економічну безпеку як «стан розвитку національної економічної системи, що забезпечує високу ефективність іï функціонування за рахунок правильного використання факторів внутрішнього розвитку та здатності ефективно протистояти зовнішньому тиску, що може призвести до порушень ii розвитку» [16, с. 189].

Інший польський дослідник К. Рачковскі зазначає, що на макрорівні економічна безпека має визначатися як «відносно збалансований ендогенний та екзогенний стан функціонування національної економіки, за якого ризик дисбалансу утримується у визначених та прийнятних (організаційно-правових) стандартах i нормах» $[17$, с. 81$]$.

Прихильники ресурсного підходу (у натій класифікаиії він п'ятий) звертають увагу на досить важливий аспект економічної безпеки держави, а саме на iï ресурсну забезпеченість. Наприклад, відповідно до дефініції, запропонованої І. Губарєвою, економічна безпека - це «стан забезпеченості необхідними ресурсами на рівні, який дає змогу досягти захищеності національних економічних інтересів від зовнішніх та внутрішніх загроз, що забезпечує незалежність національної економіки, іï стабільність та стійкість, спроможність до постійного оновлення та саморозвитку» $[18$, c. 31$]$.

Своєю чергою, М. Флейчук і Я. Гончарук трактують економічну безпеку як «стан розвитку економічної системи, що забезпечує ії ефективне функціонування засобами належного використання внутрішніх і зовнішніх чинників з урахуванням інтересів майбутніх поколінь, а також здатність до відтворення та результативного протистояння внутрішнім і зовнішнім впливам» $[19$, с. 18$]$.

У рамках цього підходу досить влучну дефініцію подає В. Бойко. Згідно із запропонованим ним підходом, під економічною безпекою варто розуміти «ресурснофункціональну та інституційну спроможність держави своєчасно протистояти загрозам в умовах постійних змін економічного середовища, забезпечувати захист національних інтересів, проводити незалежну політику у внутрішній та зовнішній сферах, формувати передумови для задоволення базових потреб людини, підвищувати добробут життя населення та забезпечувати підтримку процесів розширеного відтворення на засадах раціонального природокористування та ефективного господарювання» [20, с. 165].

Загалом, 3 нашої точки зору, питання ресурсної забезпеченості економічної безпеки держави має велике значення, проте $є$ недостатньо дослідженим у 
науковій думці. Ресурсний підхід до визначення економічної безпеки держави звертає увагу на те, що економіка як система має володіти певним ресурсом для протистояння зовнішнім та внутрішнім загрозам.

У рамках шостого (телеологічного) підходу було згруповано визначення економічної безпеки, які трунтуються на переконанні в тому, що безпека не є сприятливим збігом обставин, а результатом свідомої $i$ иілеспрямованої діяльності щодо досягнення такого стану. Як влучно зазначає В. Предборський, безпека є результатом певної свідомої, соціальної діяльності із забезпечення безпеки особи, сім'ї, суспільства, держави. Діяльність із забезпечення безпеки виникає як соціальний феномен щодо подолання суперечностей між об'єктивною реальністю - небезпекою і потребами особи, соціальних груп, суспільства і держави на засадах попередження, локалізації та обмеження $[21$, с. 13]. Отже, автор підкреслює, що економічна безпека - це не лише захищеність національних інтересів, а й готовність і здатність інститутів влади створювати механізми реалізації та захисту національних інтересів розвитку вітчизняної економіки, підтримки соціально політичної стабільності суспільства.

У рамках цього підходу найбільш змістовне визначення економічної безпеки держави, на нашу думку, надав В. Мунтіян, який окреслив іiї як «загальнонаціональний комплекс заходів, спрямованих на постійний та стабільний розвиток економіки держави, що містить механізм протидії внутрішнім і зовнішнім загрозам» [22, c. 10].

Цікаву думку наводять автори монографії «Економіка та економічна безпека держави. Теорія та практика», які розглядають економічну безпеку як специфічну «випереджувальну похідну» від економічного та політичного курсу держави, де різні ії̈ види реалізуються за допомогою відмінних, а у деяких випадках протилежних заходів [23, с. 18].

Загалом у такому розумінні забезпечення економічної безпеки $\epsilon$ не ціллю державної політики, а ії складовою частиною, тобто комплексом цілеспрямованих та свідомих дій органів публічної влади, спрямованих на реалізацію поставлених завдань, які забезпечать ії спроможність нейтралізувати зовнішні та внутрішні загрози. На нашу думку, таке твердження сьогодні набуває актуальності, оскільки економічну безпеку варто розглядати не лише як стан захищеності національних інтересів чи здатність економіки протистояти зовнішнім і внутрішнім загрозам, а й як активну політику, спрямовану на забезпечення такого стану чи здатності.

Упорядковуючи розглянуті вище підходи до визначення поняття «економічна безпека держави», систематизуємо їх у формі табл. 1.

Варто відзначити, що в науковій думці, крім згаданих вище шести підходів, досить популярним $\epsilon$ напрям, у рамках якого фахівці намагаються урахувати в дефініції економічної безпеки держави всі ключові складники та важливі аспекти. Зокрема, О. Чубукова і T Воронкова стверджують, що з позиції системного підходу економічна безпека як поліскладна система $\epsilon$ «інтегральною категорією, у предметну сферу якої входять поняття різних рівнів ієрархії, а також функціональних сфер економіки, які за взаємодії і взаємозумовленості виражають економічні відносини між суб'єктами міжнародних утворень, державою, регіонами, підприємствами, організаціями, установами, господарствами та окремими особистостями та всередині цих підсистем і елементів із приводу досягнення такого рівня розвитку економіки, за якого здійснюється задоволення потреб і гарантований захист інтересів усіх суб'єктів економіки» [24, с. 13].

В. Рожков зазначає, що економічна безпека має трактуватися різнобічно: по-перше, через характеристику стану системи, а саме: стійкість, стабільність тощо; по-друге, через здатність протидіяти внутрішнім та зовнішнім загрозам; по-третє, через можливість повноцінної реалізації всіх функцій суб'єкта господарювання; по-четверте, через повноцінне забезпечення усіма необхідними ресурсами та їх використання у виробничо-господарській діяльності [25, с. 480].

Тенденція до охоплення всіх важливих нюансів у рамках одного визначення набуває дедалі більшого поширення в українській науковій думці. Зумовлена вона бажанням поєднати різні підходи до визначення економічної безпеки держави і представити універсальну загальноприйняту дефініцію, яка стане базовою у межах дисципліни. Цінність такого підходу полягає у тому, що завдяки йому вдається сповна розкрити значення цього складного поняття. Разом із тим, виходячи із засади, окресленої вище, відповідно до якої науковотеоретичні опрацювання у сфері економічної безпеки держави мають бути максимально наближені до їх практичного застосування, можемо констатувати, що категоріально-понятійний апарат має характеризуватися точністю, змістовністю та лаконічністю.

Зауважимо, що кожен із проаналізованих вище підходів до визначення поняття «економічна безпека держави» має значну кількість прихильників. Серед них - видатні вчені, які працювали і працюють у рамках екосестейту. Кожна з наведених дефініцій акцентує увагу на одному з важливих аспектів цього поняття.

Попри те, що деякі з них досить влучно описують феномен економічної безпеки в рамках певної наукової школи, ці трактування тим не менше не можуть бути використані для дослідження в рамках інших наукових шкіл. Охарактеризовані дефініції є настільки різними, що просто не підходять для альтернативних методологічних підходів.

Тому досить важливим видається впровадження такого визначення поняття економічної безпеки держави, яке дало б змогу сформувати спільне бачення феномену економічної безпеки в рамках наукової спільноти, яка працює у цій сфері.

Із нашої точки зору, така дефініція має грунтуватися на низці важливих засад.

1. 3 огляду на практичну спрямованість екосестейту поняття економічної безпеки держави пови- 
Найбільш поширені підходи до визначення терміна «економічна безпека держави»

\begin{tabular}{|c|c|c|}
\hline Назва підходу & Визначення терміна & Учені, які презентують підхід \\
\hline Кондиціональний & $\begin{array}{l}\text { Сукупність певних умов, які забезпечують реаліза- } \\
\text { цію визначених державою завдань }\end{array}$ & $\begin{array}{l}\text { Л. Абалкін [1, с. 5], } \\
\text { А. Іларіонов }[2, \text { с. } 35], \\
\text { С. Пирожков [3, с. } 14] \text {, А. Сухоруков [4, с. } 53] \text {, } \\
\text { О. Ляшенко [5, с. } 43-44]\end{array}$ \\
\hline Якісний & $\begin{array}{l}\text { Найважливіша якісна характеристика економічної } \\
\text { системи, що визначає їі здатність підтримувати нор- } \\
\text { мальні умови функціонування та діяльності їі клю- } \\
\text { чових учасників - держави, бізнесу та громадян }\end{array}$ & $\begin{array}{l}\text { Я. Жаліло [6, с. 102], } \\
\text { Й. Янг [7, с. 67], } \\
\text { М. Єрмошенко [8, с. 29], } \\
\text { Б. Губський }[9, \text { с. 17] }\end{array}$ \\
\hline Протекціоністський & $\begin{array}{l}\text { Захищеність держави, бізнесу та громадян від вну- } \\
\text { трішніх і зовнішніх загроз }\end{array}$ & $\begin{array}{l}\text { В. Савіна[10, с. } 23] \\
\text { Т. Сак }[11, \text { с. } 337], \\
\text { В. Сенчагов }[12, \text { с. } 99]\end{array}$ \\
\hline Статичний & $\begin{array}{l}\text { Стан економіки, який дає змогу державі реалізову- } \\
\text { вати їі функції та протидіяти зовнішнім і внутрішнім } \\
\text { загрозам }\end{array}$ & $\begin{array}{l}\text { Г. Пастернак-Таранушенко [13, с. } 29] \text {, } \\
\text { В. Шлемко та I. Бінько }[14, \text { с. } 8], \\
\text { В. Андрійчук }[15, \text { с. } 14], \\
\text { 3. Стаховяк }[16, \text { с. } 189] \\
\text { К. Рачковскі }[17, \text { с. } 81]\end{array}$ \\
\hline Ресурсний & $\begin{array}{l}\text { Ресурсно-функціональна та інституційна спромож- } \\
\text { ність держави своєчасно протистояти загрозам в } \\
\text { умовах постійних змін економічного середовища, } \\
\text { забезпечувати захист національних інтересів }\end{array}$ & $\begin{array}{l}\text { I. Губарєва }[18, \text { с. } 31] \text {, } \\
\text { М. Флейчук та Я. Гончарук }[19, \text { с. } 18] \text {, } \\
\text { В. Бойко [20, с. } 165]\end{array}$ \\
\hline Телеологічний & $\begin{array}{l}\text { Безпека не є сприятливим збігом обставин, а резуль- } \\
\text { татом свідомої та цілеспрямованої діяльності щодо } \\
\text { досягнення такого стану }\end{array}$ & $\begin{array}{l}\text { В. Предборський }[21, \text { с. } 13] \\
\text { В. Мунтіян }[22, \text { с. } 10]\end{array}$ \\
\hline
\end{tabular}

Джерело: складено автором на основі [1-22]

нно бути чітким та зрозумілим. Досить часто фахівці цієї сфери «переобтяжують» визначення економічної безпеки держави. Намагаючись охопити всю багатогранність цього феномену, вони пропонують досить складні формулювання, незручні для використання у наукових дослідженнях.

2. Економічна безпека держави та ї̈ об 'єкт повинні піддаватися емпіричному опису. Досить важко оцінити та охарактеризувати «здатність» економічної системи до протидії загрозам. Значні проблеми створює також оперування такою характеристикою, як «захищеність» економічної системи.

3. Наріжним каменем теорії економічної безпеки держави є поняття «загроза». Симптоматично, що сплеск наукового й політичного інтересу до цього напряму досліджень досить міцно корелюється зі збільшенням кількості та інтенсифікацією зовнішніх і внутрішніх загроз для стабільності держави в різних сферах (військовій, політичній, економічній, соціальній тощо). У зв'язку із цим поняття економічної безпеки держави має бути тісно пов'язане $з$ існуванням загроз різного характеру, які становлять небезпеку для економічної системи.

4. Економічна безпека держави не повинна зводитися до пасивної захищеності держави від загроз, оскільки актуалізаиія нових загроз вимагає активних свідомих дій із їх нейтралізації. Із нашої точки зору, держава повинна не лише захищати економіку, а й активно протидіяти викликам та загрозам для неї.

5. Економічна безпека держави є складовою частиною національної безпеки держави. Спроби виокремлення iї як абсолютно незалежної сфери та автономної наукової дисципліни, що зосереджена на вирішенні економічних проблем, не мають сенсу та дублюватимуть напрацювання в рамках загальної економічної теорії. Політика забезпечення економічної безпеки держави має корелювати із завданнями національного масштабу.

Отже, ураховуючи вищевикладені аргументи, економічну безпеку держави, на нашу думку, слід розглядати як свідомо та цілеспрямовано скоригований у бажаному напрямі органами публічної влади стан економіки, який забезпечує стійкість держави до зовнішніх і внутрішніх системних загроз та цілеспрямованих актів інших держав, спрямованих на ії дестабілізацію.

На користь такого підходу до визначення поняття «економічна безпека держави» можна навести кілька важливих аргументів.

По-перше, аналізувати й емпірично оцінювати «стан» економіки можна набагато точніше та об’єктивніше, ніж іiї «здатність» чи «захищеність».

По-друге, таке трактування економічної безпеки держави $є$ зручнішим для використання на політико-прикладному рівні, оскільки дає можливість окреслити значення індикаторів такого стану економіки, досягнення й утримання яких є завданням політики щодо забезпечення високого рівня економічної безпеки держави.

По-третє, визначаючи економічну безпеку держави як певний цілеспрямовано скоригований стан економіки, уважаємо за доцільне підкреслити, що він не є випадковим збігом обставин чи довільно вибраною сукупністю факторів. Цей стан є результатом реалізації комплексу заходів державної політики та свідомого створення певних умов, за яких національна економіка здатна протидіяти зовнішнім і внутрішнім загрозам. 
Висновки. Високий рівень фрагментації наукової думки в рамках екосестейту виявляється вже на базовому рівні, а саме в питанні визначення економічної безпеки держави. Сьогодні існує велика кількість різних індивідуальних дефініцій, які суттєво відрізняються одна від одної.

Така термінологічна невизначеність, з одного боку, не $є$ критичною проблемою для наукової дисципліни, оскільки свідчить про високу активність методологічних пошуків. 3 іншого боку, теорія економічної безпеки держави претендує на статус зрілої наукової дисципліни, що вимагає певних усталених поглядів на феномен економічної безпеки держави.

Кожна наукова школа, без сумніву, може вбачати в економічній безпеці держави певну специфіку, що накладає відбиток на те визначення поняття, яким вона послуговується. Проте в рамках зрілої наукової дисципліни все ж таки має бути перелік загальноприйнятих базових дефініцій, а також спільне бачення об'єкта дослідження, що гарантує те, що представники різних наукових шкіл мають певне спільне розуміння об'єкта дослідження, над яким вони працюють.

Ця публікація має на меті актуалізувати наукову дискусію щодо необхідності впровадження зручного та чітко окресленого поняття «економічна безпека держави». Натомість представники різних наукових шкіл мають можливість запропонувати власні дефініції економічної безпеки держави та представити свої аргументи на користь того, що саме їхній підхід $є$ оптимальним для проведення наукових досліджень у цій сфері.

\section{Список літератури:}

1. Абалкин Л.И. Экономическая безопасность России: угрозы и их отражение. Вопросы экономики. 1994. № 12. C. 4-16.

2. Илларионов А. Критерии экономической безопасности. Вопросы экономики. 1998. № 10. С. 35-58.

3. Пирожков С.І. Методичні рекомендації щодо оцінки рівня економічної безпеки України. Київ : НІПМБ, 2003. $42 \mathrm{c}$.

4. Сухоруков А.І., Мошенський С.3., Петрук О.М. Національна економічна безпека. Житомир : Рута, 2010.384 с.

5. Ляшенко О.М. Концептуалізація управління економічною безпекою підприємства : монографія ; 2-е вид., перероб. Київ : НІСД, 2015. 348 с.

6. Жаліло Я.А. До формування категоріального апарату науки про економічну безпеку. Стратегічна панорама. 2004. № 3. C. 97-104.

7. Jiang Y. Economic Security: Redressing Imbalance. China Security. 2007. Vol. 3. № 2. P. 66-85.

8. Єрмошенко М.М. Фінансова безпека держави: національні інтереси, реальні загрози, стратегія забезпечення. Київ : КНТЕУ, 2001.

9. Губський Б.В. Економічна безпека України: методологія виміру, стан і стратегія забезпечення : монографія. Київ : ДП «Укрархбудінфор», 2001. 122 с.

10. Савин В.А. Некоторые аспекты экономической безопасности России. Международный бизнес России. 1995. № 9. С. 22-26.

11. Сак Т.В. Економічна безпека України: поняття, структура, основні тенденції. Інноваційна економіка. 2013. № 6. С. 336-340.

12. Сенчагов В. О сущности и основах стратегии экономической безопасности России. Вопросы экономики. 1995. № 1. C. 97-106.

13. Пастернак-Таранушенко Г.А. Економічна безпека держави. Методологія забезпечення : монографія. Київ : Київський економічний інститут менеджменту, 2003. 320 с.

14. Шлемко В.Т., Бінько І.Ф. Економічна безпека України: сутність і напрямки забезпечення : монографія. Київ : НІСД, 1997. 144 с.

15. Андрійчук В.Г. Економічна безпека України: стан, критерії виміру та превентивні заходи ії зміцнення. Економіка, фінанси, право. 2013. № 6. С. 12-17.

16. Stachowiak Z. Bezpieczeństwo ekonomiczne . Ekonomika obrony. Warszawa : Akademia Obrony Narodowej, 1994. S. 189 .

17. Raczkowski K. Percepcja bezpieczeństwa ekonomicznego i wyzwania dla zarządzania nim w XXI wieku. Bezpieczeństwo ekonomiczne. Wyzwania dla zarzadzania państwem. Warszawa : Wolters Kluwer, 2012.

18. Губарєва I.О., Доровськой В.А. Теоретичне визначення змісту поняття «економічна безпека». Науковий вісник Львівського державного університету внутрішніх справ. 2009. № 2. С. 31-40.

19. Гончарук Я.А., Флейчук М.І. Диференціація підходів до визначення аналізу категорії «економічна безпека держави». Науковий вісник Львівського державного університет внутрішніх справ. Серія економічна. 2009. № 2. C. 15-30. URL: https://www.lvduvs.edu.ua/seriya-ek/474-vipusk-1-2009-ekonomichni-nauki (дата звернення: 10.06.2021).

20. Бойко В.В. Еволюція розвитку та сутність економічної безпеки держави. Вісник Хмельницького національного університету. Економічні науки. 2015. № 4. Т. 1. С. 162-167.

21. Предборський В.А. Економічна безпека держави : монографія. Київ : Кондор, 2005. 391 с.

22. Мунтіян В.І. Економічна безпека України. Київ : КВШ, 1998. 462 с.

23. Економіка та економічна безпека держави. Теорія та практика : монографічний навчальний посібник / С. Давиденко та ін. Ужгород, 2017. 390 с. 
24. Чубукова О.Ю., Воронкова Т.Є. Система економічної безпеки (екосестейт): сутність, структура. Ефективна економіка. 2014. № 2. URL: http://nbuv.gov.ua/UJRN/efek_2014_2_82 (дата звернення: 10.06.2021).

25. Рожков В.О. Підходи до визначення сутності поняття економічної безпеки. Вісник Миколаӥвського національного університету імені В.О. Сухомлинського. 2016. Вип. 10. С. 478-480.

\section{References:}

1. Abalkin L.I. (1994) Ekonomicheskaya bezopasnost' Rossii: ugrozy i ikh otrazheniye [Economic security of Russia: threats and their reflection]. Voprosy èkonomiki, no. 12, pp. 4-16. (in Russian)

2. Illarionov, A. (1998) Kriterii ekonomicheskoy bezopasnosti [Criteria of economic security]. Voprosy ekonomiki, no. 10, pp. 35-58. (in Russian)

3. Pyrozhkov S.I. (2003) Metodychni rekomendatsii shchodo otsinky rivnia ekonomichnoi bezpeky Ukrainy [Methodical recommendations for assessing the level of economic security of Ukraine]. Kyiv: NIPMB, 42 p. (in Ukrainian)

4. Sukhorukov A.I., Moshensky, S.Z., Petruk, O.M. (2010) Natsionalna ekonomichna bezpeka [National economic security]. Zhytomyr: Ruta, 384 p. (in Ukrainian)

5. Liashenko O.M. (2015) Kontseptualizatsiia upravlinnia ekonomichnoiu bezpekoiu pidpryiemstva [Conceptualization of management of economic security of the enterprise]. Kyiv: NISS, 348 p. (in Ukrainian)

6. Zhalilo Ya.A. (2004) Do formuvannia katehorialnoho aparatu nauky pro ekonomichnu bezpeku [To the formation of the categorical apparatus of the science of economic security]. Strategična panorama, no. 3, pp. 97-104. (in Ukrainian)

7. Jiang Y. (2007) Economic Security: Redressing Imbalance. China Security, vol. 3, no 2, pp. 66-85. (in English)

8. Yermoshenko M.M. (2001) Finansova bezpeka derzhavy: natsionalni interesy, realni zahrozy, stratehiia zabezpechennia [Financial security of the state: national interests, real threats, security strategy]. Kyiv: KNTEU. (in Ukrainian)

9. Gubskyi B.V. (2001) Ekonomichna bezpeka Ukrainy: metodolohiia vymiru, stan i stratehiia zabezpechennia [Economic security of Ukraine: measurement methodology, state and strategy of provision]. Kyiv: DP "Ukrarkhbudinfor", 122 p. (in Ukrainian)

10. Savin V.A. (1995) Nekotoryye aspekty ekonomicheskoy bezopasnosti Rossii [Some aspects of Russia's economic security]. Mezhdunarodnyy biznes Rossii, no. 9, pp. 22-26. (in Russian)

11. Sak, T.V. (2013) Ekonomichna bezpeka Ukrainy: poniattia, struktura, osnovni tendentsii. [Economic security of Ukraine: concept, structure, main tendencies]. Innovatsiina ekonomika, no. 6, pp. 336-340. (in Ukrainian)

12. Senchagov V. (1995). O sushchnosti i osnovakh strategii ekonomicheskoĭ bezopasnosti Rossii [On the essence and foundations of Russia's economic security strategy]. Voprosy èkonomiki, no. 1, pp. 97-106. (in Russian)

13. Pasternak-Taranushenko G.A. (2003) Ekonomichna bezpeka derzhavy. Metodolohiia zabezpechennia [Economic security of the state. Support methodology]. Kyiv: Kyivskyi ekonomichnyi instytut menedzhmentu, 320 p. (in Ukrainian).

14. Shlemko V.T., Binko I.F. (1997) Ekonomichna bezpeka Ukrainy: sutnist i napriamky zabezpechennia [Economic security of Ukraine: essence and directions of maintenance]. Kyiv: NISS, 144 p. (in Ukrainian)

15. Andriichuk V.G. (2013) Ekonomichna bezpeka Ukrainy: stan, kryteriii vymiru ta preventyvni zakhody ii zmitsnennia [Economic security of Ukraine: state, measurement criteria and preventive measures to strengthen it]. Ekonomika, finansy, pravo, no. 6, pp. 12-17. (in Ukrainian)

16. Stachowiak Z. (1994) Bezpieczeństwo ekonomiczne. Stankiewicz, W. (red.). Ekonomika obrony. Warszawa: Akademia Obrony Narodowej, p. 189. (in Polish)

17. Raczkowski K. (2012) Percepcja bezpieczeństwa ekonomicznego i wyzwania dla zarządzania nim w XXI wieku. Raczkowski, K. (red.). Bezpieczeństwo ekonomiczne. Wyzwania dla zarządzania państwem. Warszawa: Wolters Kluwer. (in Polish)

18. Gubareva I.O., Dorovskoi V.A. (2009) Teoretychne vyznachennia zmistu poniattia "ekonomichna bezpeka" [Theoretical definition of the meaning of "economic security"]. Naukovyi visnyk Lvivskoho derzhavnoho universytetu vnutrishnikh sprav, no. 2, pp. 31-40. (in Ukrainian)

19. Goncharuk Ya.A., Fleichuk M.I. (2009) Dyferentsiatsiia pidkhodiv do vyznachennia analizu katehorii "ekonomichna bezpeka derzhavy" [Differentiation of approaches to the definition of the analysis of the category "economic security of the state"]. Naukovyi visnyk Lvivskoho derzhavnoho universytetu vnutrishnikh sprav. Seriia ekonomichna, no. 2, pp. 15-30. Available at: https://www.lvduvs.edu.ua/seriya-ek/474-vipusk-1-2009-ekonomichni-nauki (accessed 10 June 2021).

20. Boyko V.V. (2015) Evoliutsiia rozvytku ta sutnist ekonomichnoi bezpeky derzhavy [Evolution of development and essence of economic security of the state]. Visnyk Khmelnytskoho natsionalnoho universytetu. Ekonomichni nauky, no. 4, vol. 1, pp. 162-167. (in Ukrainian)

21. Predborskyi V. A. (2005) Ekonomichna bezpeka derzhavy [Economic security of the state]. Kyiv: Condor, $391 \mathrm{p}$. (in Ukrainian)

22. Muntian V.I. (1998) Ekonomichna bezpeka Ukrainy [Economic security of Ukraine]. Kyiv: KVSH, 462 p. (in Ukrainian).

23. Davydenko S., Yegorova O., Prykhodko V., Matishak P., Holonich Ya., at al. (2017) Ekonomika ta ekonomichna bezpeka derzhavy. Teoriia ta praktyka [Economy and economic security of the state. Theory and practice]. Uzhhorod, $390 \mathrm{p}$. (in Ukrainian)

24. Chubukova O.Yu., Voronkova T.Ye. (2014) Systema ekonomichnoi bezpeky (ekosesteit): sutnist, struktura [System of economic security (ecosestate): essence, structure]. Efektyvna ekonomika, no. 2. Available at: http://nbuv.gov.ua/UJRN/ efek_2014_2_82 (accessed 10 June 2021). 
25. Rozhkov V.O. (2016) Pidkhody do vyznachennia sutnosti poniattia ekonomichnoi bezpeky [Approaches to defining the essence of the concept of economic security]. Visnyk Mykolaivskoho natsionalnoho universytetu imeni V.O. Sukhomlynskoho, no. 10 , pp. 478-480. (in Ukrainian)

\section{ЭКОНОМИЧЕСКАЯ БЕЗОПАСНОСТЬ ГОСУДАРСТВА КАК БАЗОВОЕ ПОНЯТИЕ ЭКОСЕСТЕЙТА: В ПОИСКАХ УНИВЕРСАЛЬНОЙ ДЕФИНИЦИИ}

В статье обосновывается тезис о том, что теория экономической безопасности государства как научная дисциплина сегодня находится на начальной стадии нового этапа развития. Одновременно подчеркивается, что эта научная дисциплина в полной мере не готова к ряду вызовов. Одна из ключевых проблем, которая будет сдерживать потенциал развития экосестейта, заключается в том, что в рамках этой научной дисциплиньл существует значительное количество научных школ, большинство из которых использует собственный категориально-понятийный аппарат. При этом сущеетвенные различия начинаются уже на этапе определения базовой дефиниции указанной научной дисциилинь - экономической безопасности государства. Это является существенным препятствием для конструктивной научной дискуссии между различными специалистами в рамках экосестейта. С критической точки зрения проанализированы подходы различных научных школ и отдельных ученых к определению понятия «экономическая безопасность государства». Благодаря этому классифицированы их преимущества и недостатки. С иелью внедрения универсальной дефиниции указанного понятия предложено собственное определение экономической безопасности государства как базового понятия экосестейта, также мотивирована целесообразность применения именно такого варианта определения.

Ключевые слова: теория экономической безопасности государства, экосестейт, экономическая безопасности государства.

\section{ECONOMIC SECURITY OF THE STATE AS A BASIC CONCEPT OF ECOSESTATE: IN SEARCHING OF A UNIVERSAL DEFINITION}

The author states, that the theory of economic security of the state as a scientific discipline today is at the beginning of its new stage of development. A marked surge of interest in this topic is expected in the nearest future, that will intensify research activity in this scientific field. To meet these expectations scientific community needs a strong methodological platform, which should be based on universal and coherent categorical apparatus. However, a set of essential methodological problems may deteriorate a rise of the economic security of the state. One of the key problems is a significant number of scientific schools within the discipline. Most of them has developed their own categorical-conceptual apparatus. The author draws attention, that terminological chaos in the theory of economic security of the state as one of a serious problem for its institutionalization and development as an independent scientific discipline. It makes impossible to create a common methodological framework for discipline and undermines constructive scientific discussion between representatives of different scientific schools in this field. The huge differences between scientific schools are observed already at the stage of defining the basic definition of this scientific discipline - "economic security of the state". A plenty of various approaches can be identified withing this scientific community. The differences between defining concept of "economic security of the state" are very deep indeed. This is a significant obstacle to create a common platform for numerous groups of scientists, who are working on various aspects of this topic. To resolve this problem and find common solution the author has analysed a majority of approaches of various scientific schools and individual scientists regarding the definition of the concept of "economic security of the state". Their advantages and disadvantages have been identified. Based on knowledge obtained the author has proposed his own definition. According to it, "economic security of the state" should be treated as a state of the economy, that is intentionally and purposefully adjusted by public authorities in order to ensures the state's resilience to external and internal systemic threats and aggressive actions undertaken by other states. The author has justified the practicability of using this definition in the scientific research as well as policy-making.

Key words: economic security of the state, ecosestate, ensuring economic security of the state, object of economic security of the state. 